\title{
Effect of Different Mutagens on Some Mineral, Phytochemical and Proximate Composition of Two Red Pepper Varieties
}

\author{
N. E. Abu ${ }^{1 *}$, J. O. Omeke ${ }^{1}$ and E. O. Ojua ${ }^{1}$ \\ ${ }^{1}$ Department of Plant Science and Biotechnology, University of Nigeria, Nsukka, Enugu State, Nigeria.
}

Authors' contributions

This work was carried out in collaboration among all authors. Author NEA designed the study, supervised the study, managed the analyses of the study, edited the first draft of the manuscript. Author JOO conducted the research, collected the data and managed the literature searches, wrote the first draft of the manuscript. Author EOO conducted the research, collected the data, managed the literature searches, performed the statistical analysis, wrote the first draft of the manuscript. All authors read and approved the final manuscript.

Article Information

DOI: 10.9734/ARRB/2019/v33i230116

Editor(s):

(1) Dr. Amit Kesarwani, Assistant Professor, Department of Agronomy, College of Agriculture, G. B. Pant University of Agriculture and Technology, India. Reviewers:

(1) Michael Bordonaro, Geisinger Commonwealth School of Medicine, USA.

(2) R. Prabha, Dairy Science College, India. Complete Peer review History: http://www.sdiarticle4.com/review-history/51702

Original Research Article

Received 20 July 2019

Accepted 24 September 2019

Published 09 October 2019

\section{ABSTRACT}

Aim: This research was designed to evaluate the effects of different levels of three mutagens on two pepper varieties with a vision of choosing mutants with high values in biochemical contents that may possibly be valuable in breeding improved varieties of the plant.

Methods: Seeds of pepper were exposed to varying doses of gamma rays ${ }^{60} \mathrm{Co}(50,100,150$, and $200 \mathrm{~Gy}), \mathrm{X}$-ray doses $(40,60,80$, and $100 \mathrm{KV})$ and sodium azide $(0.01,0.02,0.03$ and $0.04 \%)$. The treated seeds and the controls were grown in the Botanic Garden of the University of Nigeria, Nsukka using a Completely Randomized Design.

Results: The result showed that vitamin $C$ and $\beta$-carotene ranged from $5.89-26.88$ and $2.62-$ $11.35 \mathrm{mg} / 100 \mathrm{~g}, \mathrm{Fe}$ and $\mathrm{Ca}(14.70$ and $13.78 \mathrm{mg} / 100 \mathrm{~g})$ were highest in Shombo at $100 \mathrm{~Gy}$. Values ranging from $0.36-2.00$ and $3.96-18.82 \mathrm{mg} / 100 \mathrm{~g}$ were recorded for flavonoid and alkaloid content across all treatment combinations. The result also revealed that at $100 \mathrm{Kv}$ and $150 \mathrm{~Gy}$, ash 
content increased in both varieties. The highest protein concentration of $9.57 \%$ was recorded at $100 \mathrm{Kv}$ of X-ray in Shombo and $6.96 \%$ at $150 \mathrm{~Gy}$ of gamma irradiation in Tatase variety. Principal component analysis explained extracted five principal axis which accounted for the variability of $72.54 \%$.

Conclusion: This study reveals that biochemical content in pepper could be improved with exposure to mutagens especially gamma irradiation.

Keywords: $\beta$-carotene; $\gamma$-rays; hidden hunger; mutagens; sodium azide; $x$-rays.

\section{INTRODUCTION}

One of the foremost challenges facing the global population in the twenty-first century is micronutrient deficiency, also called hidden hunger. The scourge of micronutrient malnutrition particularly deficiencies in micronutrients such as vitamin $A$, iron, iodine, and zinc, cause hidden hunger and is estimated to affect 2 billion people globally $[1,2]$. Hidden hunger being a chronic lack of essential vitamins and minerals poses serious effects because people often do not realize that they are suffering from hidden hunger [3]. Pregnant women and young children who show rapid growth and development are the most susceptible to deficiencies of micronutrient and thus, suffer the maximum effects which are usually unpleasant [4].

Pepper being an important agricultural crop with enormous economic importance, has the potential to provide $\beta$-carotene (a precursor of vitamin $A$ ) as well as other vitamins and minerals which can help in combating micronutrient deficiency for the ever-increasing global population. Its fruit has both nutritional and medicinal value. It is also a good source of flavor, antioxidant compounds and natural colours [5]. Pepper is considered second most important vegetable after tomatoes in the world. The fruits of pepper are consumed by every household either fresh or dried but the fresh form is mostly used in preparing delicacy [6]. The fruit colour of pepper is due to the presence of carotenoid pigments which act as antioxidants in humans. Peppers are highly cherished as they provide flavour and colouring in food $[7,8]$. Therefore, it is a common spice used all over the world [9].

There is growing interest in the manipulation of economic crops' quality through the production of new cultivars with relatively improved morphological features and nutritional composition targeted towards a specific end use. Mutations are a major source of genetic variability in crops and induced mutation has been widely used for the improvement of plant characters in different crops [10]. Inducing mutations in peppers would be useful for pepper breeding and the improvement of the crop [11]. Meanwhile, improvements in height, disease resistance, yields and nutritional qualities in major crops such as wheat, rice, barley, cotton, peanut, and cowpea, which are seed propagated crops have been obtained through induction by mutagenic agents [12,13]. Hence, this study was aimed at identifying induced variations in biochemical content among the mutants of two red pepper varieties in Nigeria that could be useful for breeding improved varieties of the plants.

\section{MATERIALS AND METHODS}

The seeds of two pepper varieties ("Shombo" and "Tatase") were used for this study. Dry pepper seeds were grouped into 13 sets. One set served as the control, 4 sets were irradiated with various doses of gamma rays $(50,100,150$ and $200 \mathrm{~Gy}$ ) in the Gamma Irradiation Facility (GIF) at Nuclear Technology Centre (NTC), Sheda Science and Technology Complex, Abuja. A different 4 sets were induced with X-rays doses of $40,60,80$ and $100 \mathrm{KV}$ at $5 \mathrm{~mA}$ per second for every X-ray dose. The X- ray induction was carried out in the Radiology section, Veterinary Teaching Hospital, University of Nigeria, Nsukka. The last 4 sets of seeds were pre-soaked in distilled water for $6 \mathrm{hrs}$. Thereafter, the seeds were soaked in various concentrations of sodium azide $(0.01,0.02,0.03$ and $0.04 \%)$ for $6 \mathrm{hrs}$. The sodium azide powders of $0.01,0.02$, $0.03,0.04 \mathrm{~g}$ were weighed using weighing balance (OHAUS AR3130) and each was dissolved in $100 \mathrm{ml}$ of distilled water and shaken to form the sodium azide concentrations. This was done at the National Centre for Energy Research and Development, University of Nigeria, Nsukka.

The seeds were grown differently according to the treatments in nursery baskets filled with topsoil mixed with poultry manure and watered daily [14]. After 6 weeks of planting, the 
seedlings from each treatment were transplanted into polybags filled with similar soil-manure content used in the nursery [15]. The plants were grown in the Botanical Garden of the University of Nigeria, Nsukka using a $3 \times 5$ factorial experimental laid out in a completely randomized design (CRD) with 10 replications for every treatment. The fruits were harvested at maturity for biochemical characterization.

The biochemical studies were carried out at the Teaching and Research Laboratory, Department of Crop Science, University of Nigeria, Nsukka. The fruits of each treatment studied were collected from the sample plants in each treatment into a bag where the fruits were mixed together and selected at random. The parameters evaluated were $\beta$ - carotene, total carotenoids, capsaicin, ascorbic acid, proximate composition which includes crude proteins, crude fat, fibre, moisture, and ash; the phytochemicals are flavonoids, alkaloids, tannin and phytate; and some mineral elements (Iron, zinc and calcium).

One gram of fruits from the respective treatments was macerated with $20 \mathrm{ml}$ of $0.4 \%$ oxalic acid for $10 \mathrm{~min}$ and centrifuged at $5000 \mathrm{rpm}$ for 5 mins. Thereafter, $5 \mathrm{ml}$ of the supernatant was transferred into a triplicate test tubes of which 2 $\mathrm{ml}$ of 2,6 , dichlorophenol indophenols (12 mg/ L) was added and mixed thoroughly by shaking. The absorbance of the resulting solution was taken at $520 \mathrm{~nm}$ at $15 \mathrm{sec}$ and $30 \mathrm{sec}$ against the corresponding blank using a UV - VIS spectrophotometer (Model; 752P, Made: Techmel and Tachmel, USA.). Vitamin C concentration of the sample was then calculated as $($ Abs $x D F \times$ volume of the cuvette $) \div E$

Where Abs = Absorbance, $\mathrm{DF}=$ Dilution factor and $E=$ Extinction coefficient [16].

In the determination of $\beta$ - carotene, $5 \mathrm{~g}$ of the respective treatments was weighed into a test tube and $20 \mathrm{ml}$ of petroleum spirit was added. This was shaken for 5 mins and decanted into another test tube, thereafter the absorbance was read at $450 \mathrm{~nm}$ using a UV - VIS spectrophotometer. The $\beta-$ carotene concentration was then calculated as follows:

$$
\begin{aligned}
& \beta-\text { carotene con. }(\mathrm{mg})= \\
& (\text { Abs } \times \text { DF } \times \text { volume of the cuvette }) \div E
\end{aligned}
$$

Ten grams $(10 \mathrm{~g})$ of the respective treatments was dissolved in $70 \mathrm{ml}$ of water at room temperature and allow for 15 mins. Six grams (6 g) of activated charcoal was added and mixed properly. The mixture was allowed to stand for 30 mins and filtered into a $400 \mathrm{ml}$ beaker using a 60 $\mathrm{ml}$ fitted glass funnel containing asbestos pad. Two (2) drops of $\mathrm{HCl}$ was added and evaporated on a steam bath to $40 \mathrm{ml}$, and transferred to a $50 \mathrm{ml}$ volumetric flask and made up with water. The absorbance of the sample was read at $233 \mathrm{~nm}$ with a UV - VIS spectrophotometer. Flavonoid was then determined by multiplying the Absorbance by 50 and divide by 1000 [16].

The alkaloids present in the pepper samples was evaluated by following a modified method outlined by Harbone [17]. Ten grams (10 g) of the ground sample was weighed into a conical flask and $100 \mathrm{ml}$ of $10 \%$ acetic acid in ethanol was added to the sample and covered to stand for 4 hours, after which it was filtered with using a Whatman filter paper No. 42 (125 mm). Thereafter, $5 \mathrm{ml}$ of concentrated ammonium hydroxide was added dropwise into the filtrate to precipitate the alkaloids. The precipitate was filtered off and washed with 1\% conc. Ammonia solution through filter pepper. The precipitate was dried in an oven at $60^{\circ} \mathrm{C}$ for 30 mins and weighed. The percentage of alkaloid was calculated.

$$
\begin{aligned}
& \text { Alkaloid }(\%) \\
& =\{(\text { weight of filter paper } \\
& + \text { alkaloid precipitate }) \\
& - \text { weight of filter paper }) \\
& \div \text { weight of the grounded sample used }\} \\
& \times 100 \div 1
\end{aligned}
$$

Determination of tannins was carried out using Folin Denis Spectrophotometric method [18]. Ten grams $(10 \mathrm{~g})$ of the respective treatments sample was weighed into a $250 \mathrm{ml}$ conical flask containing $10 \mathrm{ml}$ of distilled water and agitated. The mixture was allowed to stand for at room temperature with shaking at every 5 mins for 30 mins and centrifuged at 5000 rpm for 10 mins. Two and a half (2.5) $\mathrm{ml}$ of the supernatant was pipetted into a $50 \mathrm{ml}$ volumetric flask and similar $2.5 \mathrm{ml}$ of a standard, tannic acid was pipette into another $50 \mathrm{ml}$ flask followed by addition of $2.5 \mathrm{ml}$ of saturated trioCarbonate (iv) solution and diluted with water to the $50 \mathrm{ml}$ mark. This was allowed to stand for 90 mins at room temperature and absorbance was taken with a spectrophotometer. Tannin percentage concentration was calculated as \% Tannin = $(A n / A s) x C \times(100 / W) x(V f / V a)$; Where An = Absorbance of test sample, As = Absorbance of the standard solution, $\mathrm{C}=$ Concentration of the standard solution, $\mathrm{W}=$ Weight of sample, $\mathrm{Vf}=$ 
Total volume of the extract and Vs $=$ Volume of extract analysed [18].

Determination of phytate was done by weighing $0.5 \mathrm{~g}$ was of each simple into different $500 \mathrm{ml}$ round bottom flask and extracted with $100 \mathrm{ml}$ of $24 \% \mathrm{HCL}$ for $1 \mathrm{hr}$ at room temperature. The extract was decanted and filtered using a Whatman filter paper No. 42 (125 mm). Five (5) $\mathrm{ml}$ of the filtrate was pipetted into a $25 \mathrm{ml}$ flask and made up with water, after which, $15 \mathrm{ml}$ of $0.07 \mathrm{M}$ sodium chloride was added. The absorbance was read at $520 \mathrm{~nm}$. A standard curve with phytic acid was prepared and blanked [16].

Ash was determined following the standard method described by the AOAC [16]. A silica dish was heated to $600^{\circ} \mathrm{C}$, cooled in a desiccator and weighed. The sample $(2 \mathrm{~g})$ was transferred into a silica dish and weighed. The dish was placed in the muffle furnace and ashed (heated at $600^{\circ} \mathrm{C}$ ) in a furnace for 3 hours and allowed to cool. Percentage ash content was calculated as (Weight of ash/Weight of fresh sample) $x$ 100/1.

Determination of crude protein content was done using the micro-Kjeldahl method outlined by Pearson [18]. Oven dried ground plant material $(0.5 \%)$ was transferred into $30 \mathrm{ml} \mathrm{Kjeldahl} \mathrm{flask}$ carefully and $20 \mathrm{ml}$ of concentrated $\mathrm{H}_{2} \mathrm{SO}_{4}$ added. The catalyst (a mixture of selenium oxide and $\left.\mathrm{CuSO}_{4}\right)(1 \mathrm{~g})$ was also added. This was heated cautiously on digestion rack under fume hood until a clear greenish solution appears. After the digest has cleared, the mixture was heated for another 30 minutes and allowed to cool. About $10 \mathrm{ml}$ of distilled water was added to avoid caking and then transferred to the Kjeldahl distillation apparatus. $20 \mathrm{ml}$ of $40 \% \mathrm{NaOH}$ were added to the mixture and allowed to distill. The distillate was later titrated to first pink colour with $0.01 \mathrm{HCl}$ and the concentration of proteins calculated using the formula as shown below:

$$
\begin{aligned}
& \% \text { Nitrogen }=(\text { Titre value } \times 14.1 \times 0.01 \times 100 \times 5) \\
& \div(1000 \times \text { weight of sample })
\end{aligned}
$$

\% Protein

$=\%$ Nitrogen $x 6.5$ (where 6.5 is a constant)

Total carotenoids, iron, zinc, and calcium were also determined using the official methods described by the Association of Official Analytical Chemists [16].

Data collected were subjected to analysis of variance using GenStat Discovery Edition 4 software and significant means were separated using the least significance difference test obtained from the same software. The correlation and principal component analysis were done using IBM SPSS Statistics 20 software.

\section{RESULTS AND DISCUSSION}

Assessment of the nutrient composition of "Tatase" and "Shombo" plants induced with different doses of mutagens showed marked variability that can be exploited. The nutritive value is the primary factor that determines the economic benefit of a vegetable crop. It was observed from the present study that "Tatase" and "Shombo", like any other cultivated vegetables in the tropics, contain a reasonable amount of nutrients in suitable proportions. There were variations in vitamin $\mathrm{C}, \quad \beta$-carotene and capsaicin contents of "Tatase" and "Shombo" plants induced with different concentrations/doses of the mutagens. The result of the mineral content of the harvested fruits after exposure recorded significant differences $(P=.05)$ across the mutagens (Table 1). Results also recorded that the two red pepper varieties responded to the mutagens differently. Higher Vitamin C content in Shombo fruits was observed in treatment to sodium azide with $0.03 \%$ concentration recording significantly $(\mathrm{P}=.05)$ the highest mean vitamin $\mathrm{C}$ content $(26.88 \pm 0.02 \mathrm{mg} / 100 \mathrm{~g})$. On the other hand, Tatase fruits from $X$-rays concentration of $40 \mathrm{Kv}$ had significantly $(P=.05)$ the highest vitamin $C$ concentration $(21.72 \pm 0.30 \mathrm{mg} / 100 \mathrm{~g})$. The $\beta$ carotene content across the pepper fruits ranged from 3.65 to $11.35 \mathrm{mg} / 100 \mathrm{~g}$ in Shombo variety and 2.62 to $7.90 \mathrm{mg} / 100 \mathrm{~g}$ in Tatase variety. This was an indication that Shombo fruits had higher $\beta$-carotene than Tatase, however, while there was a significant increase of $\beta$-carotene in Shombo with the mutagens, Tatase had a negative effect of the mutagens on its $\beta$-carotene content. Fruits from plants induced with $150 \mathrm{~Gy}$ had the highest $\beta$-carotene in Shombo (11.35 \pm $0.60 \mathrm{mg} / 100 \mathrm{~g}$ ). There was a higher concentration of capsaicin content with gamma irradiation than other mutagens used in the study. The Fe content was drastically reduced in Shombo variety and increased in Tatase following treatment with sodium azide and $\mathrm{X}$-rays as compared to the control (Fig. 1). Calcium concentration was at maximum with $150 \mathrm{~Gy}$ of gamma irradiation (13.78 mg/100 g) (Fig. 2) while zinc concentration in the two red pepper varieties was also affected by the mutagens in different ways with $0.01 \%$ sodium azide 
treatment recording the maximum value of $(18.60$ mg/ 100 g) (Fig. 3).

Maximum flavonoids were recorded in plants of both cultivars raised from seeds treated with $0.04 \%$ sodium azide and the control. Concentrations of gamma rays exposure did not affect the alkaloid concentration in both varieties, although Shombo produced the highest alkaloid $(19.01 \mathrm{mg} / 100 \mathrm{~g})$ at $60 \mathrm{Kv}$. Moreover, tannin and phytate significantly reduced with treatment to gamma irradiation than other mutagens (Table 2).

There were significant $(P=.05)$ effects of sodium azide, X-rays and gamma rays on all the proximate parameters investigated (Table 3 ). Fruits of Shombo plants treated with $40 \mathrm{Kv} \mathrm{X}$-rays contained $85.90 \%$ moisture which was similar to those treated with $0.02 \%$ sodium azide. However, Tatase fruits harvested in plants from seeds treated with gamma irradiation at $200 \mathrm{~Gy}$ produced maximum moisture of $93.93 \%$. The result revealed that at $100 \mathrm{Kv}$ of X-rays, ash content increased in both varieties (9.50 and $9.65 \%$ ), a similar effect was also observed at 150 Gy gamma irradiation dose across both varieties. For the fat concentration across the treated seeds, the maximum concentration of 3.06 and $4.90 \%$ in Shombo and Tatase were respectively observed when seeds were exposed to $0.04 \%$ sodium azide and $40 \mathrm{Kv}$ X-rays. On the other hand, the fibre of fruits from plants exposed to $X$ rays and gamma irradiation were higher than those treated with sodium azide. Additionally, the protein concentration ranged from $1.33-9.75 \%$ in Shombo and $1.32-6.83 \%$ in Tatase. The highest protein concentration of $9.57 \%$ was recorded at $100 \mathrm{Kv}$ of X-ray in Shombo and
$6.96 \%$ at 150 Gy of gamma irradiation in Tatase variety (Table 3).

The increased variability in biochemical content of the treated material is a reliable indication of the effects of mutagens. Sodium azide as earlier been reported to have increased the alkaloid concentration in the leaf and bark of Khaya senigalences [19]. Previous study had also shown that gamma irradiation had a significant effect on morphology and yield traits of Cajanus cajan [12]. As reported by Udensi and Ntui [12], frequently observed symptoms in the low-or highdose-irradiated plants are enhancement or inhibition of biological responses. More so, Ashraf [20] had attributed the possible increase in $\beta$ - carotene to the production of a reactive oxygen species by gamma irradiation that induces oxidative stress and ultimately affects structural and functional molecules of a plant by causing a disturbance in normal metabolic pathways. However, this increase in biochemical content could be as a result of biological response towards induced oxidative damage in the cell.

Correlation analysis is liable to measure the level of association between two traits which must be understood in any breeding programme. Biological characters are naturally correlated as a result of pleiotropy and linkage $[21,22]$. Result obtained revealed a significant positive relationship between $\beta$-carotene and ash, fibre, $\mathrm{Ca}$, flavonoids, alkaloid. Pearson correlation analysis using two-tailed test showed that $\beta$ carotene had a significant weak positive relationship $(P<.01)$ with ash, fibre, calcium, flavonoids and alkaloid and correlated negatively with fat and Vitamin C. However, ash had a

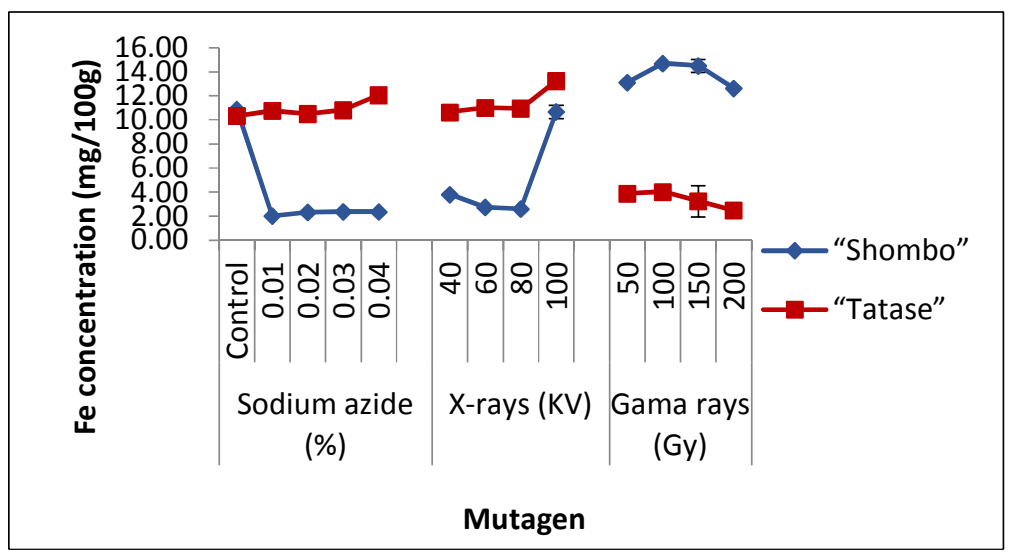

Fig. 1. Effect of mutagens on iron (Fe) contents of two red pepper varieties 


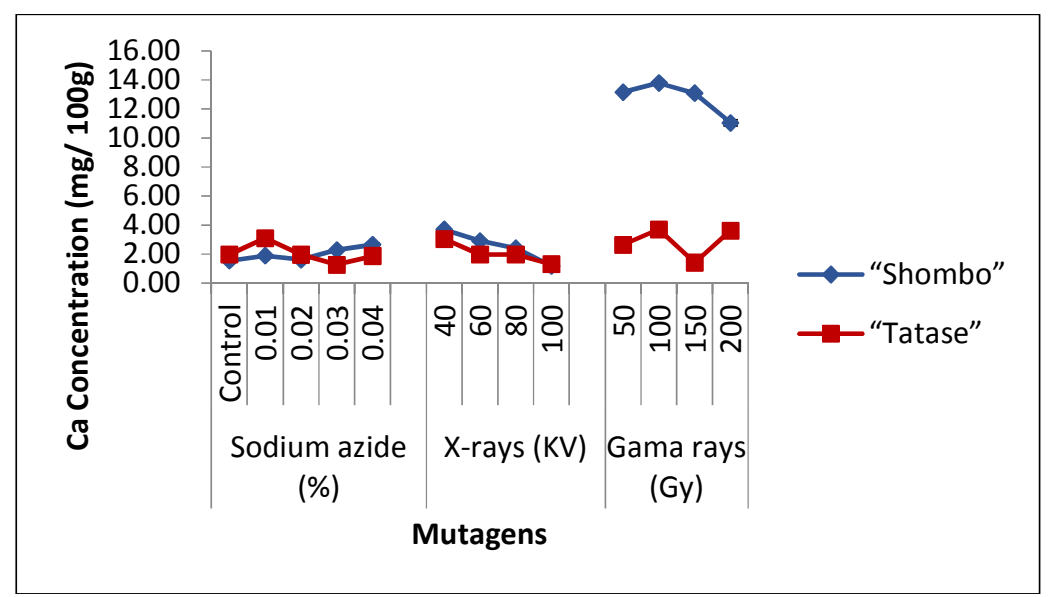

Fig. 2. Effect of mutagens on calcium (Ca) contents of two red pepper varieties

strong positive relationship with fibre and protein (Table 4). The importance of this relationship simply implies that the traits are influenced by the same genes in the same direction [23]. Therefore, could be harnessed as selection markers for breeding and subsequent improvement of pepper with increased $\beta$ carotene content.

For path coefficient analysis, $\beta$ - carotene was used as dependent variable. The direct effect (path coefficient) and the indirect effect of $\beta$ carotene influencing traits monitored in induced pepper are presented in Table 5 . The result showed that the different micronutrient traits had a varied magnitude of direct effects on $\beta$ carotene. It was observed that total carotene $(0.1640)$ had the highest direct effects which were all positive. This was followed by fat (0.1316) and fibre (0.1469) while alkaloids
(0.000) had no direct effect on $\beta$ - carotene (Table 5). Summarily, the path coefficient analysis further showed that fibre contributed directly to the $\beta$-carotene content of pepper.

The principal component analysis (PCA) of the micronutrients analyzed is presented in Table 6 . The result reveals that the first five principal axis was of importance in explaining the variation in the micronutrients. The first $\mathrm{PC}$ axis $\left(\mathrm{PC}_{1}\right)$ explained $31.44 \%$ of the variation, $\mathrm{PC}_{2}$ explained $14.98 \%, \mathrm{PC}_{3}$ explained $10.68 \%, \mathrm{PC}_{4}$ explained $8.97 \%$ and $\mathrm{PC}_{5}$ explained $6.47 \%$ of the variance. The axis all explained a total variance of $72.54 \%$. In addition, using varimax rotation method of PCA, the micronutrients that contributed significantly to PC1 were ash, fiber, and protein. $\mathrm{Fe}, \mathrm{Ca}$ and $\beta$ - carotene contributed to $\mathrm{PC}_{2}$, phytate contributed to $\mathrm{PC}_{3}, \mathrm{Zn}$ and phytate contributed to $\mathrm{PC}_{4}$ while flavonoids contributed to

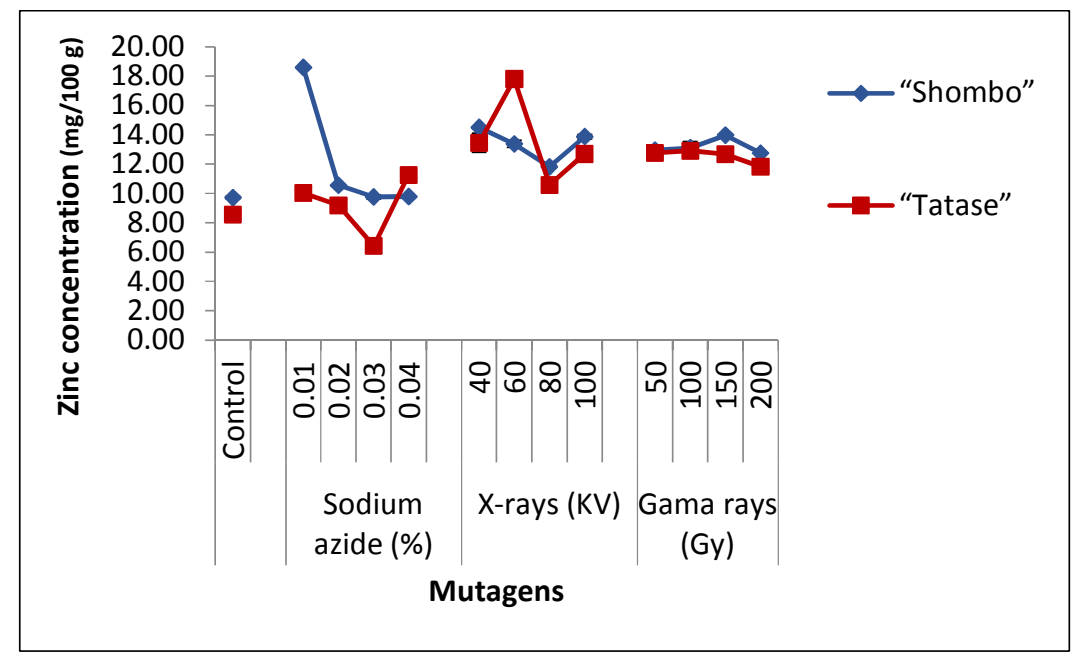

Fig. 3. Effect of mutagens on zinc contents of two red pepper varieties 


\section{Table 1. Effect of mutagens on mineral contents of two red pepper varieties}

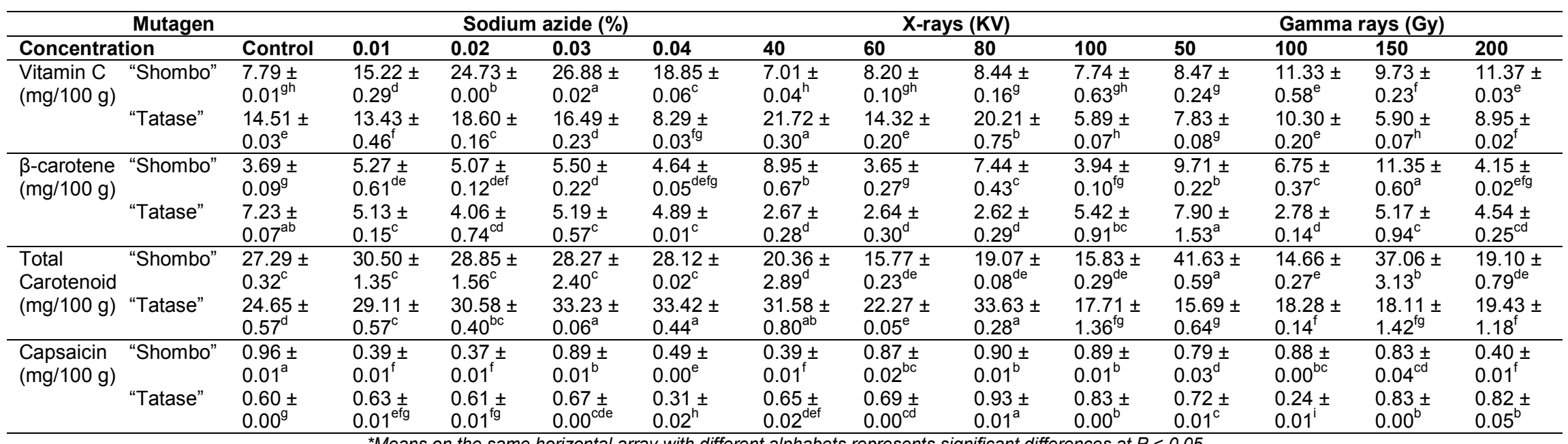


Table 2. Effect of mutagens on some phytochemical contents of two red pepper varieties

\begin{tabular}{|c|c|c|c|c|c|c|c|c|c|c|c|c|c|c|}
\hline \multicolumn{3}{|c|}{ Mutagen } & \multicolumn{4}{|c|}{ Sodium azide (\%) } & \multicolumn{4}{|c|}{ X-rays (KV) } & \multicolumn{4}{|c|}{ Gamma rays (Gy) } \\
\hline Concentration & & Control & 0.01 & 0.02 & 0.03 & 0.04 & 40 & 60 & 80 & 100 & 50 & 100 & 150 & 200 \\
\hline $\begin{array}{l}\text { Flavonoids } \\
(\mathrm{mg} / 100 \mathrm{~g})\end{array}$ & $\begin{array}{l}\text { "Shombo" } \\
\text { "Tatase" }\end{array}$ & $\begin{array}{l}0.75 \pm \\
0.01^{\mathrm{b}} \\
2.00 \pm \\
0.00^{\mathrm{a}}\end{array}$ & $\begin{array}{l}0.60 \pm \\
0.01^{\text {bcd }} \\
0.75^{\text {de }} \\
0.06^{\text {de }}\end{array}$ & $\begin{array}{l}0.62 \pm \\
0.00^{\text {bcd }} \\
0.57 \pm \\
0.03^{f} \\
\end{array}$ & $\begin{array}{l}0.62 \pm \\
0.00^{\text {bcd }} \\
0.90 \pm \\
0.01^{\text {bc }} \\
\end{array}$ & $\begin{array}{l}1.53 \pm \\
0.01^{\mathrm{a}} \\
0.82 \pm \\
0.09^{\mathrm{cd}} \\
\end{array}$ & $\begin{array}{l}0.38 \pm \\
0.02^{\mathrm{e}^{\mathrm{a}}} \\
0.84 \pm \\
0.01^{\mathrm{cd}} \\
\end{array}$ & $\begin{array}{l}0.61 \pm \\
0.01^{\text {bcd }} \\
0.71 \pm \\
0.02^{\mathrm{e}^{-}} \\
\end{array}$ & $\begin{array}{l}0.36 \pm \\
0.03^{\mathrm{e}^{-}} \\
0.42 \pm \\
0.01^{\mathrm{gh}}\end{array}$ & $\begin{array}{l}0.51 \pm \\
0.01^{\text {cde }} \\
0.98 \pm \\
0.00^{\mathrm{b}} \\
\end{array}$ & $\begin{array}{l}1.60 \pm \\
0.24^{\mathrm{a}} \\
0.68 \pm \\
0.00^{\mathrm{e}}\end{array}$ & $\begin{array}{l}0.45 \pm \\
0.01^{\text {de }} \\
0.47 \pm \\
0.00^{9^{9}} \\
\end{array}$ & $\begin{array}{l}0.73 \pm \\
0.02^{\mathrm{bc}} \\
0.97 \pm \\
0.01^{\mathrm{b}} \\
\end{array}$ & $\begin{array}{l}0.65 \pm \\
0.02^{\text {bcd }} \\
0.37 \pm \\
0.03^{\mathrm{h}} \\
\end{array}$ \\
\hline $\begin{array}{l}\text { Alkaloid } \\
(\mathrm{mg} / 100 \mathrm{~g})\end{array}$ & $\begin{array}{l}\text { "Shombo" } \\
\text { "Tatase" }\end{array}$ & $\begin{array}{l}11.25 \pm \\
0.40^{d} \\
9.45 \pm \\
0.01^{d}\end{array}$ & $\begin{array}{l}12.59 \pm \\
0.06^{\mathrm{c}} \\
13.18 \pm \\
0.15^{\mathrm{c}}\end{array}$ & $\begin{array}{l}11.96 \pm \\
0.38^{\text {cd }} \\
13.22 \pm \\
0.58^{\mathrm{c}} \\
\end{array}$ & $\begin{array}{l}6.92 \pm \\
0.02^{f} \\
15.23 \pm \\
0.33^{b} \\
\end{array}$ & $\begin{array}{l}9.22 \pm \\
0.35^{\mathrm{e}^{\mathrm{c}}} \\
12.72 \pm \\
0.01^{\mathrm{c}}\end{array}$ & $\begin{array}{l}18.82 \pm \\
0.01^{a} \\
14.64 \pm \\
0.98^{b}\end{array}$ & $\begin{array}{l}19.01 \pm \\
0.06^{\mathrm{a}} \\
3.96 \pm \\
0.29^{\mathrm{e}}\end{array}$ & $\begin{array}{l}18.58 \pm \\
0.01^{\mathrm{a}} \\
18.02 \pm \\
0.00^{\mathrm{a}}\end{array}$ & $\begin{array}{l}16.40 \pm \\
0.29^{b} \\
18.30 \pm \\
0.29^{\mathrm{a}}\end{array}$ & $\begin{array}{l}18.23 \pm \\
0.38^{\mathrm{a}} \\
18.23 \pm \\
0.34^{\mathrm{a}} \\
\end{array}$ & $\begin{array}{l}18.03 \pm \\
0.41^{\mathrm{a}} \\
18.67 \pm \\
0.24^{\mathrm{a}} \\
\end{array}$ & $\begin{array}{l}18.30 \\
\pm 0.23^{\mathrm{a}} \\
18.40 \\
\pm 0.31^{\mathrm{a}} \\
\end{array}$ & $\begin{array}{l}16.73 \pm \\
1.13^{\mathrm{b}} \\
18.23 \pm \\
0.38^{\mathrm{a}} \\
\end{array}$ \\
\hline $\begin{array}{l}\text { Tannin } \\
(\mathrm{mg} / 100 \mathrm{~g})\end{array}$ & $\begin{array}{l}\text { "Shombo" } \\
\text { "Tatase" }\end{array}$ & $\begin{array}{l}0.42 \pm \\
0.00^{\mathrm{b}} \\
0.66 \pm \\
0.00^{\mathrm{c}}\end{array}$ & $\begin{array}{l}0.34 \pm \\
0.00^{\text {cd }} \\
0.86 \pm \\
0.04^{b}\end{array}$ & $\begin{array}{l}0.35 \pm \\
0.01^{\mathrm{c}} \\
0.61 \pm \\
0.01^{\mathrm{d}^{\mathrm{d}}}\end{array}$ & $\begin{array}{l}0.35 \pm \\
0.01^{\mathrm{c}} \\
1.69 \pm \\
0.01^{\mathrm{a}}\end{array}$ & $\begin{array}{l}0.69 \pm \\
0.01^{\mathrm{a}} \\
0.57 \pm \\
0.01^{\mathrm{de}}\end{array}$ & $\begin{array}{l}0.23 \pm \\
0.02^{\mathrm{fg}} \\
1.71 \pm \\
0.03^{\mathrm{a}}\end{array}$ & $\begin{array}{l}0.37 \pm \\
0.02^{\mathrm{bc}} \\
0.48 \pm \\
0.00^{f}\end{array}$ & $\begin{array}{l}0.20 \pm \\
0.02^{\mathrm{g}} \\
0.22 \pm \\
0.00^{\mathrm{hi}}\end{array}$ & $\begin{array}{l}0.28 \pm \\
0.00^{\mathrm{e}} \\
0.55 \pm \\
0.00^{\mathrm{e}}\end{array}$ & $\begin{array}{l}0.65 \pm \\
0.02^{\mathrm{a}} \\
0.39 \pm \\
0.01^{\mathrm{g}}\end{array}$ & $\begin{array}{l}0.26 \pm \\
0.03^{\mathrm{ef}^{\mathrm{f}}} \\
0.25 \pm \\
0.01^{\mathrm{h}}\end{array}$ & $\begin{array}{l}0.38 \pm \\
0.01^{\mathrm{bc}} \\
0.54 \pm \\
0.01^{\mathrm{e}}\end{array}$ & $\begin{array}{l}0.30 \pm \\
0.03^{\mathrm{de}} \\
0.18 \pm \\
0.00^{\mathrm{i}}\end{array}$ \\
\hline $\begin{array}{l}\text { Phytate } \\
(\mathrm{mg} / 100 \mathrm{~g})\end{array}$ & $\begin{array}{l}\text { "Shombo" } \\
\text { "Tatase" }\end{array}$ & $\begin{array}{l}0.77 \pm \\
0.00^{\mathrm{ef}} \\
0.92 \pm \\
0.03^{\mathrm{bc}}\end{array}$ & $\begin{array}{l}9.47 \pm \\
0.18^{\mathrm{a}} \\
1.11 \pm \\
.08^{\mathrm{b}} \\
\end{array}$ & $\begin{array}{l}0.05 \pm \\
0.00^{\mathrm{h}} \\
0.89 \pm \\
0.01^{\mathrm{c}}\end{array}$ & $\begin{array}{l}0.97 \pm \\
0.01^{d^{d}} \\
0.88 \pm \\
0.00^{c}\end{array}$ & $\begin{array}{l}0.65 \pm \\
0.00^{f} \\
0.98 \pm \\
0.00^{\mathrm{bc}}\end{array}$ & $\begin{array}{l}0.08 \pm \\
0.00^{\mathrm{h}} \\
0.94 \pm \\
0.17^{\mathrm{bc}}\end{array}$ & $\begin{array}{l}0.32 \pm \\
0.03^{\mathrm{g}} \\
0.89 \pm \\
0.05^{\mathrm{c}}\end{array}$ & $\begin{array}{l}3.97 \pm \\
0.01^{\mathrm{b}} \\
0.81 \pm \\
0.03^{\mathrm{c}}\end{array}$ & $\begin{array}{l}3.08 \pm \\
0.00^{\mathrm{c}} \\
2.52 \pm \\
0.10^{\mathrm{a}}\end{array}$ & $\begin{array}{l}0.87 \pm \\
0.01^{\mathrm{de}} \\
0.55 \pm \\
0.04^{\mathrm{d}}\end{array}$ & $\begin{array}{l}0.66 \pm \\
0.01^{f} \\
0.38 \pm \\
0.02^{\mathrm{de}}\end{array}$ & $\begin{array}{l}0.92 \pm \\
0.02^{d^{d}} \\
0.23 \pm \\
0.07^{\mathrm{e}} \\
\end{array}$ & $\begin{array}{l}0.33 \pm \\
0.00^{\mathrm{g}} \\
0.96 \pm \\
0.02^{\mathrm{bc}}\end{array}$ \\
\hline
\end{tabular}

Table 3. Effect of mutagens on some proximate contents of two red pepper varieties

\begin{tabular}{|c|c|c|c|c|c|c|c|c|c|c|c|c|c|c|}
\hline \multicolumn{3}{|c|}{ Mutagen } & \multicolumn{4}{|c|}{ Sodium azide (\%) } & \multicolumn{4}{|c|}{ X-rays (KV) } & \multicolumn{4}{|c|}{ Gamma rays (Gy) } \\
\hline Concent & ion & Control & 0.01 & 0.02 & 0.03 & 0.04 & 40 & 60 & 80 & 100 & 50 & 100 & 150 & 200 \\
\hline $\begin{array}{l}\text { Moisture } \\
(\%)\end{array}$ & $\begin{array}{l}\text { "Shombo" } \\
\text { "Tatase" }\end{array}$ & $\begin{array}{l}76.45 \pm \\
0.03^{\mathrm{e}} \\
89.01 \pm \\
0.01^{\mathrm{b}}\end{array}$ & $\begin{array}{l}78.15 \pm \\
0.09^{\text {de }} \\
77.10 \pm \\
0.69^{\text {fg }}\end{array}$ & $\begin{array}{l}85.45 \pm \\
0.89^{\mathrm{a}} \\
79.15 \pm \\
0.61^{\text {def }} \\
\end{array}$ & $\begin{array}{l}82.50 \pm \\
.29^{b} \\
75.70 \pm \\
0.17^{g} \\
\end{array}$ & $\begin{array}{l}82.51 \pm \\
0.01^{\mathrm{b}} \\
77.45 \pm \\
0.32^{\text {efg }}\end{array}$ & $\begin{array}{l}85.90 \pm \\
0.52^{\mathrm{a}} \\
79.55 \pm \\
0.03^{\mathrm{de}}\end{array}$ & $\begin{array}{l}79.05 \pm \\
0.84^{\mathrm{cd}} \\
85.25 \pm \\
0.14^{\mathrm{c}} \\
\end{array}$ & $\begin{array}{l}63.60 \pm \\
1.21^{\mathrm{g}} \\
86.00 \pm \\
0.00^{\mathrm{c}}\end{array}$ & $\begin{array}{l}76.20 \pm \\
0.69^{\mathrm{e}} \\
81.50 \pm \\
0.29^{\mathrm{d}} \\
\end{array}$ & $\begin{array}{l}83.03 \pm \\
1.42^{\mathrm{b}} \\
84.23 \pm \\
1.53^{\mathrm{c}} \\
\end{array}$ & $\begin{array}{l}65.60 \pm \\
0.82^{\mathrm{g}} \\
85.43 \pm \\
1.63^{\mathrm{c}} \\
\end{array}$ & $\begin{array}{l}73.37 \pm \\
0.23^{f} \\
81.10 \pm \\
0.49^{d} \\
\end{array}$ & $\begin{array}{l}81.07 \pm \\
0.73^{\mathrm{bc}} \\
93.93 \pm \\
1.07^{\mathrm{a}} \\
\end{array}$ \\
\hline Ash (\%) & $\begin{array}{l}\text { "Shombo" } \\
\text { "Tatase" }\end{array}$ & $\begin{array}{l}2.65 \pm \\
0.09^{g h} \\
2.06 \pm \\
0.03^{f}\end{array}$ & $\begin{array}{l}2.30 \pm \\
0.40^{\mathrm{hi}} \\
2.70 \pm \\
0.06^{\mathrm{e}^{\mathrm{e}}}\end{array}$ & $\begin{array}{l}3.35 \pm \\
0.03^{9} \\
3.00 \pm \\
0.06^{\mathrm{e}}\end{array}$ & $\begin{array}{l}3.00 \pm \\
0.12^{\mathrm{gh}} \\
2.95 \pm \\
0.20^{\mathrm{e}}\end{array}$ & $\begin{array}{l}1.56 \pm \\
0.03^{i} \\
3.00 \pm \\
0.17^{\mathrm{e}^{\mathrm{i}}}\end{array}$ & $\begin{array}{l}5.15 \pm \\
0.49^{f} \\
1.25 \pm \\
0.14^{\mathrm{g}}\end{array}$ & $\begin{array}{l}9.30 \pm \\
0.12^{\mathrm{a}} \\
2.80 \pm \\
0.00^{\mathrm{e}}\end{array}$ & $\begin{array}{l}7.20 \pm \\
0.17^{d} \\
2.30 \pm \\
0.00^{f}\end{array}$ & $\begin{array}{l}9.50 \pm \\
0.00^{\mathrm{a}} \\
9.65 \pm \\
0.09^{\mathrm{a}}\end{array}$ & $\begin{array}{l}8.13 \pm \\
0.09^{\mathrm{bc}} \\
8.13^{ \pm} \\
0.13^{\mathrm{b}}\end{array}$ & $\begin{array}{l}6.07 \pm \\
0.12^{ \pm} \\
6.63^{ \pm} \\
0.27^{d}\end{array}$ & $\begin{array}{l}8.90 \pm \\
0.30^{\mathrm{ab}} \\
9.50 \pm \\
0.17^{\mathrm{a}}\end{array}$ & $\begin{array}{l}7.40 \pm \\
0.59^{\mathrm{cd}} \\
7.47 \pm \\
0.03^{\mathrm{c}}\end{array}$ \\
\hline Fat (\%) & $\begin{array}{l}\text { "Shombo" } \\
\text { "Tatase" }\end{array}$ & $\begin{array}{l}2.65 \pm \\
0.09^{b} \\
1.65 \pm \\
0.09^{\mathrm{e}}\end{array}$ & $\begin{array}{l}2.80 \pm \\
0.12^{\mathrm{b}} \\
3.45 \pm \\
0.03^{\mathrm{b}}\end{array}$ & $\begin{array}{l}1.95 \pm \\
0.03^{\mathrm{c}} \\
2.40 \pm \\
0.17^{d}\end{array}$ & $\begin{array}{l}1.45 \pm \\
0.03^{d^{d}} \\
2.65 \pm \\
0.20^{d^{d}}\end{array}$ & $\begin{array}{l}3.06 \pm \\
0.03^{\mathrm{a}} \\
3.55 \pm \\
0.03^{\mathrm{b}}\end{array}$ & $\begin{array}{l}0.60 \pm \\
0.00^{f g} \\
4.90 \pm \\
0.06^{\mathrm{a}}\end{array}$ & $\begin{array}{l}0.60 \pm \\
0.00^{\text {fg }} \\
3.05 \pm \\
0.03^{c}\end{array}$ & $\begin{array}{l}1.00 \pm \\
0.06^{\mathrm{e}} \\
3.10 \pm \\
0.06^{\mathrm{c}}\end{array}$ & $\begin{array}{l}0.75 \pm \\
0.03^{f} \\
0.55 \pm \\
0.03^{f}\end{array}$ & $\begin{array}{l}0.67 \pm \\
0.09^{f} \\
0.53 \pm \\
0.07^{f}\end{array}$ & $\begin{array}{l}1.07 \pm \\
0.03^{\mathrm{e}^{\mathrm{a}}} \\
0.47 \pm \\
0.03^{f}\end{array}$ & $\begin{array}{l}1.03 \pm \\
0.03^{\mathrm{e}^{\mathrm{a}}} \\
0.50 \pm \\
0.06^{f}\end{array}$ & $\begin{array}{l}0.47 \pm \\
0.07^{g} \\
0.63 \pm \\
0.07^{f}\end{array}$ \\
\hline
\end{tabular}


Abu et al.; ARRB, 33(2): 1-13, 2019; Article no.ARRB.51702

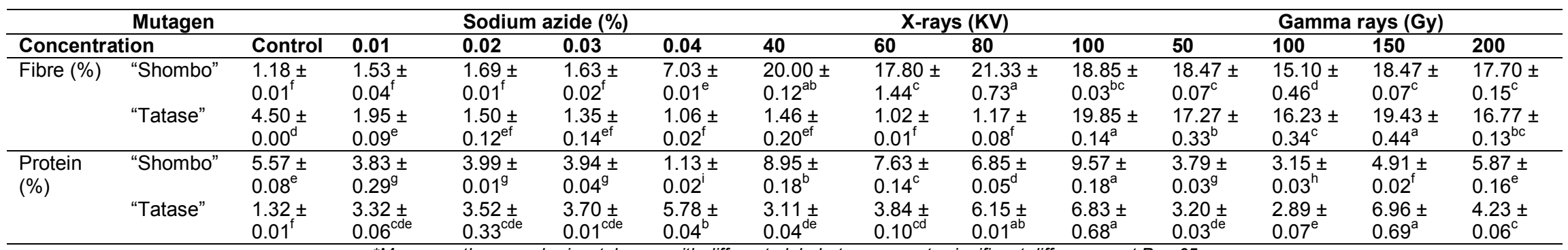

${ }^{*}$ Means on the 0.010 .040 .04

Table 4. Pooled correlation matrix of proximate, mineral and phytochemical of the two Nigerian pepper varieties

\begin{tabular}{|c|c|c|c|c|c|c|c|c|c|c|c|c|c|c|c|c|}
\hline & 1 & 2 & 3 & 4 & 5 & 6 & 7 & 8 & 9 & 10 & 11 & 12 & 13 & 14 & 15 & 16 \\
\hline 1. Moisture & 1 & & & & & & & & & & & & & & & \\
\hline 2. Ash & -0.12 & 1 & & & & & & & & & & & & & & \\
\hline 3. Fat & -0.06 & $-0.837^{\pi \pi}$ & 1 & & & & & & & & & & & & & \\
\hline 4. Fibre & -0.12 & $0.906^{\pi \pi}$ & $-0.850^{\star \pi}$ & 1 & & & & & & & & & & & & \\
\hline 5. Protein & -0.18 & $0.529^{\pi \pi}$ & $-0.380^{\star \pi}$ & $0.475^{\pi x}$ & 1 & & & & & & & & & & & \\
\hline 6. Fe & $-0.276^{*}$ & 0.00 & 0.20 & -0.10 & -0.02 & 1 & & & & & & & & & & \\
\hline 7. $\mathrm{Ca}$ & $-0.268^{*}$ & $0.341^{* *}$ & $-0.327^{* \pi}$ & $0.408^{\star x}$ & -0.11 & $0.459^{\star \pi}$ & 1 & & & & & & & & & \\
\hline 8. $\mathrm{Zn}$ & -0.02 & $0.292^{x *}$ & -0.15 & $0.306^{\pi x}$ & $0.267^{*}$ & -0.07 & 0.21 & 1 & & & & & & & & \\
\hline 9. Vitamin C & 0.17 & $-0.706_{\pi \pi}^{\pi \pi}$ & $0.550^{x x}$ & $-0.716^{\star \pi}$ & $-0.495^{\pi \times}$ & -0.14 & -0.20 & $-0.306^{\star \pi}$ & $1 \ldots$ & & & & & & & \\
\hline 10. $\beta$-carotene & -0.18 & $0.322^{x x}$ & $-0.397^{* x}$ & $0.430^{n x}$ & -0.01 & 0.11 & $0.504^{\pi *}$ & 0.05 & $-0.294^{\pi *}$ & 1 & & & & & & \\
\hline 11. Total carotene & 0.02 & $-0.484^{m x}$ & $0.548^{n}$ & $-0.535^{x x}$ & $-0.331^{\text {1x }}$ & $0.300^{\pi x}$ & 0.14 & $-0.235^{x}$ & $0.427^{* x}$ & 0.20 & 1 & & & & & \\
\hline 12. Capsaicin & -0.285 & 0.329 & -0.18 & 0.21 & 0.269 & 0.20 & 0.08 & -0.10 & -0.15 & 0.09 & -0.10 & 1 & & & & \\
\hline 13. Flavonoids & $0.241^{*}$ & -0.17 & 0.12 & -0.13 & $-0.455^{\star \pi}$ & 0.20 & 0.07 & $-0.285^{*}$ & 0.04 & $0.232^{x}$ & $0.321^{\pi *}$ & -0.08 & 1 & & & \\
\hline 14. Alkaloid & -0.08 & $0.420^{* x}$ & $-0.371^{\star x}$ & $0.503^{x *}$ & 0.11 & -0.05 & $0.373^{* \pi}$ & 0.00 & $-0.381^{\text {** }}$ & $0.311^{* *}$ & -0.08 & 0.02 & -0.19 & 1 & & \\
\hline 15. Tannin & -0.08 & $-0.402^{x+x}$ & $0.587^{* x}$ & $-0.422^{\text {xix }}$ & $-0.353^{\text {xx }}$ & $0.277^{x}$ & -0.15 & $-0.348^{\text {xx }}$ & $0.309^{x \times}$ & -0.13 & $0.415^{x x}$ & -0.07 & $0.383^{\text {*x }}$ & -0.07 & 1.00 & \\
\hline 16. Phytate & $-0.281^{*}$ & -0.06 & 0.11 & -0.07 & 0.07 & -0.18 & -0.18 & $0.455^{-x}$ & -0.03 & 0.02 & 0.05 & -0.04 & -0.12 & -0.16 & -0.12 & 1.00 \\
\hline
\end{tabular}

${ }^{*}$ values are significant at $P=.05$; **values are highly significant at $P<.01 ;(-)$ negative association between compared traits 
Table 5. Direct (Underlined) and indirect effects of proximate, mineral, phytochemical concentration to $\beta$ - carotene content

\begin{tabular}{|c|c|c|c|c|c|c|c|c|c|c|c|c|c|c|c|}
\hline & Moisture & Ash & Fat & Fibre & Protein & Fe & $\mathrm{Ca}$ & $\mathrm{Zn}$ & Vitamin C & $\begin{array}{l}\text { Total } \\
\text { carotene }\end{array}$ & Capsaicin & Flavonoids & Alkaloid & Tannin & Phytate \\
\hline Moisture & $\underline{0.0269}$ & -0.0055 & -0.0038 & 0.0075 & -0.0005 & -0.0046 & 0.0106 & -0.0003 & 0.0031 & -0.0016 & 0.0020 & -0.0096 & 0.0000 & -0.0004 & 0.0048 \\
\hline Ash & -0.0055 & $\underline{0.0778}$ & -0.0847 & -0.0968 & 0.0024 & -0.0001 & -0.0229 & 0.0071 & -0.0227 & 0.0547 & -0.0039 & 0.0115 & -0.0003 & -0.0036 & 0.0018 \\
\hline Fat & -0.0038 & -0.0847 & 0.1316 & 0.1182 & -0.0023 & 0.0073 & 0.0285 & -0.0047 & 0.0230 & -0.0805 & 0.0028 & -0.0105 & 0.0003 & 0.0069 & -0.0042 \\
\hline Fibre & 0.0075 & -0.0968 & $\overline{0.1182}$ & $\underline{0.1469}$ & -0.0030 & 0.0039 & 0.0376 & -0.0102 & 0.0316 & -0.0830 & 0.0035 & -0.0120 & 0.0004 & 0.0053 & -0.0028 \\
\hline Protein & -0.0005 & 0.0024 & -0.0023 & $\overline{-0.0030}$ & $\underline{0.0003}$ & 0.0000 & 0.0004 & 0.0004 & -0.0009 & 0.0022 & -0.0002 & 0.0018 & 0.0000 & -0.0002 & -0.0001 \\
\hline $\mathrm{Fe}$ & -0.0046 & 0.0000 & 0.0073 & 0.0039 & 0.0000 & $\underline{0.0101}$ & -0.0111 & -0.0006 & -0.0016 & -0.0122 & -0.0009 & -0.0049 & 0.0000 & 0.0009 & 0.0019 \\
\hline $\mathrm{Ca}$ & 0.0106 & -0.0229 & 0.0285 & 0.0376 & 0.0004 & $\overline{-0.0111}$ & $\underline{0.0579}$ & -0.0044 & 0.0055 & 0.0136 & 0.0008 & 0.0041 & 0.0002 & 0.0012 & -0.0045 \\
\hline $\mathrm{Zn}$ & -0.0003 & 0.0071 & -0.0047 & -0.0102 & 0.0004 & -0.0006 & $\overline{-0.0044}$ & $\underline{0.0076}$ & -0.0031 & 0.0083 & 0.0004 & 0.0060 & 0.0000 & -0.0010 & -0.0042 \\
\hline Vitamin C & 0.0032 & -0.0227 & 0.0230 & 0.0316 & -0.0009 & -0.0016 & 0.0055 & 0.0021 & $\underline{0.0133}$ & -0.0199 & 0.0007 & -0.0011 & 0.0001 & 0.0012 & 0.0004 \\
\hline $\begin{array}{l}\text { Total } \\
\text { carotene }\end{array}$ & -0.0013 & 0.0547 & -0.0805 & -0.0830 & 0.0022 & -0.0122 & 0.0136 & 0.0083 & -0.0199 & $\underline{0.1640}$ & -0.0017 & 0.0314 & -0.0001 & -0.0055 & 0.0021 \\
\hline Capsaicin & 0.0020 & -0.0039 & 0.0028 & 0.0035 & -0.0002 & -0.0009 & 0.0008 & 0.0004 & 0.0007 & -0.0017 & $\underline{0.0018}$ & -0.0008 & 0.0000 & 0.0001 & -0.0002 \\
\hline Flavonoids & -0.0096 & 0.0115 & -0.0105 & -0.0120 & 0.0018 & -0.0049 & 0.0041 & 0.0060 & -0.0011 & 0.0314 & -0.0008 & $\underline{0.0585}$ & -0.0001 & -0.0030 & -0.0030 \\
\hline Alkaloid & 0.0000 & -0.0003 & 0.0003 & 0.0004 & 0.0000 & 0.0000 & 0.0002 & 0.0000 & 0.0001 & -0.0001 & 0.0000 & -0.0001 & $\underline{0.0000}$ & 0.0000 & 0.0000 \\
\hline Tannin & -0.0004 & -0.0036 & 0.0069 & 0.0053 & -0.0002 & 0.0009 & 0.0012 & -0.0010 & 0.0012 & -0.0055 & 0.0001 & -0.0030 & 0.0000 & $\underline{0.0011}$ & 0.0004 \\
\hline Phytate & 0.0048 & 0.0018 & -0.0042 & -0.0028 & -0.0001 & 0.0019 & -0.0045 & -0.0042 & 0.0004 & 0.0021 & -0.0002 & -0.0030 & 0.0000 & 0.0004 & $\underline{0.0110}$ \\
\hline
\end{tabular}

Table 6. Principal Component Analysis (PCA) of proximate, mineral and phytochemical in two Nigerian pepper varieties

\begin{tabular}{|c|c|c|c|c|c|c|c|}
\hline & & \multirow[t]{2}{*}{ Communalities } & \multicolumn{5}{|c|}{ Principal component axis } \\
\hline & & & 1 & 2 & 3 & 4 & 5 \\
\hline \multirow[t]{3}{*}{ Initial Eigen values } & Total & - & 5.03 & 2.40 & 1.71 & 1.44 & 1.04 \\
\hline & $\%$ of Variance & - & 31.44 & 14.98 & 10.68 & 8.97 & 6.47 \\
\hline & Cumulative \% & - & 31.44 & 46.43 & 57.11 & 66.08 & 72.55 \\
\hline Moisture & & 0.69 & -0.18 & -0.23 & -0.74 & 0.17 & 0.17 \\
\hline Ash & & 0.88 & 0.92 & - & - & -0.11 & 0.12 \\
\hline Fat & & 0.87 & -0.87 & - & 0.33 & - & - \\
\hline Fibre & & 0.92 & 0.94 & 0.12 & -0.14 & - & - \\
\hline Protein & & 0.65 & 0.60 & -0.32 & 0.28 & -0.33 & - \\
\hline $\mathrm{Fe}$ & & 0.65 & - & 0.64 & 0.39 & -0.25 & 0.12 \\
\hline $\mathrm{Ca}$ & & 0.78 & 0.38 & 0.70 & 0.12 & 0.27 & -0.25 \\
\hline $\mathrm{Zn}$ & & 0.70 & 0.40 & -0.30 & 0.38 & 0.55 & 0.10 \\
\hline Vitamin C & & 0.67 & -0.77 & - & - & - & -0.25 \\
\hline$\beta$ - carotene & & 0.66 & 0.39 & 0.60 & - & 0.37 & - \\
\hline
\end{tabular}


Abu et al.; ARRB, 33(2): 1-13, 2019; Article no.ARRB. 51702

\begin{tabular}{|c|c|c|c|c|c|c|}
\hline & \multirow[t]{2}{*}{ Communalities } & \multicolumn{5}{|c|}{ Principal component axis } \\
\hline & & 1 & 2 & 3 & 4 & 5 \\
\hline Total carotene & 0.66 & -0.58 & 0.49 & 0.18 & 0.22 & - \\
\hline Capsaicin & 0.58 & 0.28 & 0.17 & 0.29 & -0.59 & 0.22 \\
\hline Flavonoids. & 0.89 & -0.31 & 0.51 & -0.35 & 0.14 & 0.62 \\
\hline Alkaloid & 0.69 & 0.49 & 0.31 & -0.18 & - & -0.57 \\
\hline Tannin & 0.54 & -0.59 & 0.36 & - & -0.22 & - \\
\hline Phytate & 0.77 & - & -0.33 & 0.60 & 0.50 & 0.24 \\
\hline
\end{tabular}


$\mathrm{PC}_{5}$ (Table 6). Principal component analysis similarly explained the variations observed in the micronutrients of pepper. The communality values obtained in this study ranged from 0.54 0.92. The high communality obtained from fibre content strongly suggests its contribution to the variation observed amongst the treatments.

\section{CONCLUSION}

This study reveals that biochemical traits in pepper were sensitive to different mutagens in different ways. Sodium azide was useful in increasing vitamin $\mathrm{C}$, total carotenoid, $\mathrm{Fe}, \mathrm{Zn}$, and flavonoids level. There was a considerable increase in the $\beta$-carotene, $\mathrm{Ca}$ and proximate levels with $\gamma$-rays while the increase in vitamin $\mathrm{C}$, total carotenoid, $\mathrm{Fe}$, and proximate levels was also evident with exposure of plants to $X$ - rays. Also ash, fibre, calcium, flavonoids, and alkaloids are important factors to be considered for selection in pepper breeding program that is targeted towards $\beta$-carotene improvement. Based on the submission of other researcher that have confirmed the stability of mutants in subsequent generations [24,25], these mutagens if monitored and directed carefully, could proffer significant alternative for improving biochemical content in $C$. annuum to combat the problem of nutrient deficiency among the population.

\section{COMPETING INTERESTS}

Authors have declared that no competing interests exist.

\section{REFERENCES}

1. Tulchinsky TH. Micronutrient deficiency conditions: Global Health Issues. Public Health Rev. 2010;32:243-255.

Available:https://doi.org/10.1007/BF03391 600.

2. Grune $T$, Lietz G, Palou A, Ross AC, Stahl W, Tang G, Thurnham D, Yin SA, Biesalski HK. Beta-carotene is an important vitamin A source for humans. J. Nutr. 2010;140 (12):2268S-2285S.

Available:https://doi.org/10.3945/jn.109.11 9024

3. Meshram II, Arlappa N, Balakrishna N, Laxmaiah A, Mallikarjun RK, Gal RC, Ravindranath M, Sharad KS, Brahmam GN. Prevalence and determinants of undernutrition and its trends among preschool tribal children of Maharashtra State, India. J Trop Pediatr. 2012;58(2):125-32.
Available:https://doi.org/10.1093/tropej/fmr 035

4. Black RE, Victora CG, Walker SP, Bhutta Z, Christian P, deOnis M. Maternal and child under nutrition and overweight in low-income and middleincome countries. Lancet. 2013;382:42751.

Available:http://doi.org/10.1016/S01406736(13)60937-X

5. Howard LR, Talcott ST, Brenes $\mathrm{CH}$ Villalon B. Changes in phytochemical and antioxidant activity of selected pepper cultivars (Capsicum species) as influenced by maturity. J Agric Food Chem. 2000;48: 1713-1720.

Available:https://doi.org/10.1021/jf990916t

6. Ogunlade I, Alebiosu AA, Osasona AI. Proximate, mineral composition, antioxidant activity and total phenolic content of some pepper varieties (Capsicum species). Int. J. Biol. Chem. Sci. 2013;6:2221-2227.

Available:https://doi.org/10.4314/ijbcs.v6i5. 28.

7. Adetula OA, Olakojo SA. Genetic characterization and evaluation of some pepper accessions, Capsicum frutescens (L.). The Nigerian "Shombo" collections. Am-Eurasian J Agric Environ Sci. 2006; 1:273-281.

8. Abu NE, Uguru MI, Obi IU. Genotype by trait relations of yield and yield components in aromatic peppers (Capsicum annuum L) based on GT biplot. J Plant Breed Crop Sci. 2011;3:382-390. Available:http://doi.org/10.5897/JPBCS11. 050.

9. Mohammed B, Gabel M, Karlsson LM. Nutritive values of the drought tolerant food and fodder crop. Afri J Agric Sci. 2013;8: 2326-2333.

Available:https://doi.org/10.5897/AJAR12.1 296.

10. Elangovan R, Pavadai P. Effect of gamma rays on germination, morphological and yield characters of bhendi (Abelmoschus esculentus [L.] Moench). Hortic Biotechnol Res. 2015;1:35-38.

Available:https://doi.org/10.19071/jhcbt.20 15.v1.2916.

11. Bosland PW, Votava EJ. Peppers: vegetable and spice capsicums. cambridge: $\mathrm{CABI} ; 2012$.

12. Udensi O, Ntui VO. Evaluating the performance of amiprophos methyl and $\mathrm{y}$ irradiated seeds on growth and yield traits 
of pigeon pea. Int J Agric Biol. 2013;15:885 $-890$.

13. Iwo GA, Amadi CO, Eleazu CO, Ukpabi $\mathrm{JU}$. Induced mutagenesis on ginger for improved yield components and oleoresin content. Can J Plant Breed. 2013;1:90-96.

14. Ojua EO, Abu NE, Ojua DN, Omeke JO, Eze NM, Okanwu JO, Chukwuma CK. Effect of gamma irradiation on fruits of three pepper varieties. International Journal of Science and Technolge. 2019;7 (1):26-30.

Available:https://doi.org/10.24940/theijst/20 19/v7/i1/ST1901-020

15. Ojua E, Abu N, Omeke J. Data for: sensitivity of some micronutrient composition in two Nigerian peppers to treatment with different mutagens. Mendeley Data. 2018;1.

Available:http://dx.doi.org/10.17632/kyvd29 yxcj.1.

16. AOAC. Official methods of analysis. Association of official analytical chemists: Washington D.C; 2005.

17. Harborne JB. Phytochemical methods. chapman and hall Itd., London. 1973;49188.

18. Pearson D. The chemical analysis of foods. $7^{\text {th }}$ ed. Churchill living stone, Edinburgh; 1976.

19. Mostafa GG. Effect of some chemical mutagens on the growth, phytochemical composition and induction of mutations in Khaya senegalensis. Int J Plant Breed Genet. 2015;9:57-67.

Available:https://doi.org/10.3923/ijpbg.201 5.57.67.

20. Ashraf M, Cheema AA, Rsahid M, Qamar $Z$. Effect of gamma rays on $M_{1}$ generation in basmati rice. Paskistan J Bot. 2003;35 (5):791-795.

21. Rosario MF, Silva MAN, Coelho AAD, Savino VJM, Dias CTS. Canonical discriminate analysis applied to broiler chicken performance. J Ani Sci. 2008;2: 419-424.

Available:https://doi.org/10.1017/S1751731 107001012.

22. Ikpeme EV, Kooffreh ME, Udensi OU, Ekerette EE, Ashishie LA, Ozoje MO. Multivariate-based genetic diversity analysis of three genotypes of Nigerian local chickens (Gallus domestica). Inter J Sci Res Methodol. 2016;5:1-12.

23. Etukudo OM, Blna-ibor O, Ekerette EE. Comparative study of egg quality traits of black skinned and white-skinned ectotypes of snails (Archachatina marginata) based on four whorls in Calabar, Nigeria. $\mathrm{J}$ Biol Sci. 2015;15:98-101.

Available:https://doi.org/10.3923/jbs.2015. 98.101.

24. Udensi O, Ntia MI, Obianwa CU. Optimizing induced mutation technique for the improvement of agronomic traits in pigeon pea [Cajanus cajan (L.) Millsp.] cultivar. Comunicata Scientiae. 2014;5:267 $-278$.

25. Brisibe EA, Udensi O, Ntui VO, Otu PA, Chukwurah PN. Sensitivity of some quantitative and yield characters of 'Egusi' melon (Colocynthis citrullus L.) to treatment with microtubule inhibitors. African Journal of Plant Science. 2011;5 (13):759-766.

Available:https://doi.org/10.5897/AJPS11.2 40.

(c) 2019 Abu et al.; This is an Open Access article distributed under the terms of the Creative Commons Attribution License (http://creativecommons.org/licenses/by/4.0), which permits unrestricted use, distribution, and reproduction in any medium, provided the original work is properly cited.

Peer-review history:

The peer review history for this paper can be accessed here: http://www.sdiarticle4.com/review-history/51702 